\title{
Evaluation of nociception and edema in experimental sciatic nerve compression model in Wistar rats treated with cryotherapy
}

\author{
Avaliação da nocicepção e edema em modelo experimental de compressão do nervo isquiático \\ em ratos Wistar tratados com crioterapia
}

Jhenifer Karvat ${ }^{1}$, Camila Mayumi Martin Kakihata1, Lizyana Vieira ${ }^{1}$, Juliana Sobral Antunes ${ }^{1}$, Lucinéia de Fátima Chasko Ribeiro ${ }^{1}$, Gladson Ricardo Flor Bertolini ${ }^{1}$

DOI 10.5935/1806-0013.20160073

\section{ABSTRACT}

BACKGROUND AND OBJECTIVES: Considering the scarcity of studies addressing cryotherapy to treat peripheral nervous injuries, this study aimed at evaluating nociception and edema in an experimental sciatic nerve compression model with Wistar rats treated with cryotherapy.

METHODS: Forty-two rats were randomly distributed in groups: G1 - control, euthanized in the $15^{\text {th }}$ postoperative day; G2, G3 and G4 - submitted to sciatic nerve compression and euthanized in the $3^{\text {rd }}, 8^{\text {th }}$ and $15^{\text {th }}$ postoperative day, respectively; G5, G6 and G7 - submitted to sciatic nerve compression and treated with cryotherapy, euthanized in the $3^{\text {rd }}, 8^{\text {th }}$ and $15^{\text {th }}$ postoperative day, respectively. Nociception evaluation at injury site and plantar region, and observation of edema were performed before injury, in the $2^{\text {nd }}$ postoperative day and in the day corresponding to euthanasia of each injured group. Mixed ANOVA was used for statistical analysis, considering significant 5\%.

RESULTS: There has been decreased pain threshold at injury site in injured groups, however there has been increase in the same groups with regard to evaluations in the $8^{\text {th }}$ and $15^{\text {th }}$ postoperative days. Nociception in the plantar region was similar to previous one, however threshold has not increased. With regard to edema, there has been significant difference in evaluations in the $3^{\text {rd }}$ and $2^{\text {nd }}$ postoperative days corresponding to G1, G4 and G7, which had higher values as compared to pre-injury.

CONCLUSION: Cryotherapy has not increased nociceptive threshold or decreased the edema.

Keywords: Cold therapy, Edema, Immersion, Nociception, Peripheral nerve trauma.

1. Universidade Estadual do Oeste do Paraná, Departamento de Biociências e Saúde, Cascavel, PR, Brasil.

Submitted in February 04, 2016.

Acepted for publication in June 21, 2016.

Conflic of interests: none - Sponsoring sources: Fundação Araucária. Coordenação de Aperfeiçoamento de Pessoal de Nível Superior (CAPES).

Correspondence to:

Rua Universitária, 2069. Jardim Universitário

85819-110 Cascavel, PR, Brasil.

E-mail: gladson_ricardo@yahoo.com.br

(C) Sociedade Brasileira para o Estudo da Dor

\section{RESUMO}

JUSTIFICATIVA E OBJETIVOS: Considerando a carência de estudos a respeito da crioterapia como tratamento de lesão nervosa periférica, este estudo teve como objetivo avaliar a nocicepção e o edema em modelo experimental de compressão do nervo isquiático em ratos Wistar, tratados com crioterapia.

MÉTODOS: Foram utilizados 42 ratos separados aleatoriamente nos grupos: G1 - controle, eutanasiado no $15^{\circ}$ de pósoperatório; G2, G3 e G4 - submetidos à compressão do nervo isquiático, eutanasiados no $3^{\circ}, 8^{\circ}$ e $15^{\circ}$ de pós-operatório, respectivamente; G5, G6 e G7 - submetidos à compressão do nervo isquiático e tratados com crioterapia, eutanasiados no $3^{\circ}$, $8^{\circ}$ e $15^{\circ}$ de pós-operatório, respectivamente. As avaliaçóes da nocicepção no local da lesão e na região plantar, e a verificação do edema aconteceram nos momentos pré-lesão, $2^{\circ}$ dia de pósoperatório e no dia correspondente a eutanásia de cada grupo lesionado. A análise estatística foi pela ANOVA mista, com nível de significância de $5 \%$.

RESULTADOS: No local da lesão houve diminuição do limiar doloroso nos grupos lesionados, entretanto, apresentou aumento do mesmo nos grupos relacionados às avaliaçóes do $8^{\circ}$ e $15^{\circ}$ de pós-operatório. Já a nocicepção realizada na região plantar foi semelhante à anterior, porém o limar não aumentou. Com relação ao edema, houve diferença significativa na avaliação realizada no $3^{\circ}$ e no $2^{\circ}$ dias de pós-operatório correspondentes ao G1, G4 e G7, que apresentaram valores maiores comparadas com a pré-lesão.

CONCLUSÁO: A crioterapia não auxiliou no aumento do limiar nociceptivo e redução de edema.

Descritores: Edema, Imersão, Nociceptividade, Terapia por frio, Traumatismo do nervo periférico.

\section{INTRODUCTION}

Peripheral nerves are target for crush, compression and transection injuries. Among most common lower limb nervous injuries there is sciatic nerve injury which leads to functional, sensory and motor loss, eliciting permanent impact on patients and their functional capacity to perform daily activities ${ }^{1-3}$.

In addition, soon after nervous injury there is inflammatory response, chemotaxis to immune system cell site and production of chemical substances which contribute to changes in vascular patency, increased local blood flow, edema and hyperalgesia $^{4,5}$. 
Aiming at accelerating injured peripheral nerves recovery, different treatments have been proposed. Cold therapy is therapeutic application of cold, which decreases blood flow, metabolism and nervous conduction velocity, resulting in decreased inflammatory reaction, pain and delayed edema formation $^{6,7}$.

Cold therapy may be applied with ice packets, massage with ice, sprays and immersion. Immersion, however, cools down a larger area as compared to other modalities. Cold therapy for approximately 20 minutes is effective to reach therapeutic effects ${ }^{7}$.

Cold therapy, however, applied in areas of superficial nerves may induce temporary injuries ${ }^{6}$. On the other hand, there are also few studies on the use of cold therapy to treat peripheral nervous injuries.

In light of the above, this study aimed at evaluating nociception and edema in an experimental model of sciatic nerve compression in Wistar rats treated with cold therapy.

\section{METHODS}

This is a quantitative, experimental and randomized study. Sample was made up of 42 Wistar male rats, mean weigh of $327 \pm 24.84 \mathrm{~g}$ and mean age of 10 weeks, obtained from the Central Vivarium, Universidade Estadual do Oeste do Paraná (UNIOESTE), and maintained in the sectorial Vivarium, Laboratório de Estudo das Lesöes e Recursos Fisioterapêuticos (LELRF), in standard polypropylene boxes, in temperature of $23 \pm 1^{\circ} \mathrm{C}$, with photoperiod of $12 \mathrm{~h}$, receiving free food and water.

Animals were randomly distributed in seven groups:

- Group 1 (G1, n=6) - control, made up of animals not submitted to nervous compression and cold therapy, euthanized in the $15^{\text {th }}$ day of the experiment;

- Group 2 (G2, n=6) - submitted to nervous compression with no treatment and euthanized in the $3^{\text {rd }}$ postoperative day (PO);

- Group 3 (G3, n=6) - submitted to nervous compression with no treatment and euthanized in the $8^{\text {th }} \mathrm{PO}$ day;

- Group $4(\mathrm{G} 4, \mathrm{n}=6)$ - submitted to nervous compression with no treatment and euthanized in the $15^{\text {th }} \mathrm{PO}$ day;

- Group 5 (G5, n=6) - submitted to nervous compression and treated with cold therapy, euthanized in the $3^{\text {rd }} \mathrm{PO}$ day;

- Group $6(\mathrm{G} 6, \mathrm{n}=6)$ - submitted to nervous compression and treated with cold therapy, euthanized in the $8^{\text {th }} \mathrm{PO}$ day;

- Group 7 (G7, n=6) - submitted to nervous compression and treated with cold therapy, euthanized in the $15^{\text {th }} \mathrm{PO}$ day.

\section{Experimental model of sciatic nerve compression}

Animals were initially kept in LELRF for two weeks to adapt to the study site. Before surgical procedure, animals were weighed and anesthetized with intraperitoneal ketamine hydrochloride $(95 \mathrm{mg} / \mathrm{kg})$ and xylazine hydrochloride $(12 \mathrm{mg} / \mathrm{kg})$. After anesthesia and observation of animals' consciousness status (observed by the lack of motor response to tail and interdigital folds clipping), animals were placed in the prone position and trichotomy was performed at surgical procedure site.

Then, an incision was made parallel to femoral biceps muscle fibers, exposing left pelvic limb sciatic nerve, with subsequent compression with haemostatic clamp for 30 seconds. Clamping pressure was standardized for all animals and carried out by the same individual, using as reference the closing of the second rack tooth ${ }^{8}$. Finally, external suture was performed with Catgut 4.0 thread, iodine was applied on the incision and animals were lodged in the same pre-surgical conditions, separated according to their experimental group.

\section{Treatment protocol}

Animals were manually contained and right pelvic limb was immersed in a $1440 \mathrm{~cm}^{3}$ container $(20 \mathrm{~cm} \times 12 \mathrm{~cm} \times 6 \mathrm{~cm})$ with water and ice at a temperature of $5 \pm 2{ }^{\circ} \mathrm{C}$, for 20 minutes ${ }^{9}$. Groups G5, G6 and G7 were treated soon after surgical procedure. So, G5 has received a single treatment session and for G6 and G7 treatment went on from the $3^{\text {rd }}$ to the $7^{\text {th }} \mathrm{PO}$ day. G2, G3 and G4 animals were also positioned according to the treatment protocol, however container had no water and ice.

\section{Nociception evaluation}

Nociception was evaluated with a digital Von Frey filament ${ }^{10}$. Test was performed with animals manually contained and the tip of the equipment applied to surgery site on right pelvic limb. Polypropylene tip was applied perpendicularly to the area, with gradual pressure increase and as soon as the animal flinched, the test was interrupted to record flinching threshold. Stimulation was also applied to plantar region of the affected limb and, for such, animals were maintained in a raised box with screen floor. So, the filament was positioned and local pressure was applied until right pelvic limb flinching. This evaluation was performed in the following moments: pre-injury, $2^{\text {nd }} \mathrm{PO}$ day and in the day corresponding the euthanasia of each injured group, being that G1 was evaluated in the same moments as groups submitted to injury, however with euthanasia in the $15^{\text {th }}$ day after beginning of experiment. Flinching threshold data were presented based on mean of animals of the same group.

\section{Edema evaluation}

Edema was evaluated by fluid volume change by means of Insight brand paw hydroplestimometer. In this test, right pelvic limb was placed in a container with water until complete immersion of ankle joint, and water displacement was measured. This evaluation was performed soon after nociception evaluation in the same moments.

\section{Statistical analysis}

Results were analyzed by means of the SPSS 18.0 program (Statistical Package for the Social Sciences). Comparison between groups and evaluations was made among CG, injury and injury with cold therapy euthanized in the same PO day. Shapiro-Wilk test was used for data normality and, when positive, mixed ANOVA statistical test was applied with accepted significance level of $\alpha=0.05$. 
Project was approved by the Ethics Committee for the Use of Animals (CEUA), UNIOESTE (07/15/2014).

\section{RESULTS}

Nociception at injury site

Nociception at injury site shows significant difference among G1, G2 and G5 $[\mathrm{F}(2 ; 30)=40.2 ; \mathrm{p}<0.001]$, being flinching threshold value for G2 and G5 lower than for G1. There has also been difference among evaluations: those performed in the $2^{\text {nd }}$ and $3^{\text {rd }} \mathrm{PO}$ day had lower thresholds as compared to pre-injury (Figure 1A). G1, G2 and G6 had also statistical difference $[F(2 ; 30)=18,8 ; p<0,001]$, being that $G 3$ and $G 6$ had lower values as compared to $\mathrm{G} 1$. In addition, pre-injury evaluation has shown higher threshold as compared to $2^{\text {nd }} \mathrm{PO}$ day, while this had lower threshold as compared to euthanasia day ( $\left.8^{\text {th }} \mathrm{PO}\right)$ (Figure $\left.1 \mathrm{~B}\right)$. With regard to G1, G4 and G7 there has been statistical difference $[F(2 ; 30)=33,7 ; p<0,001]$, being that G4 and G7 had lower thresholds as compared to G1. There has been significant difference in pre-injury evaluation, which has shown

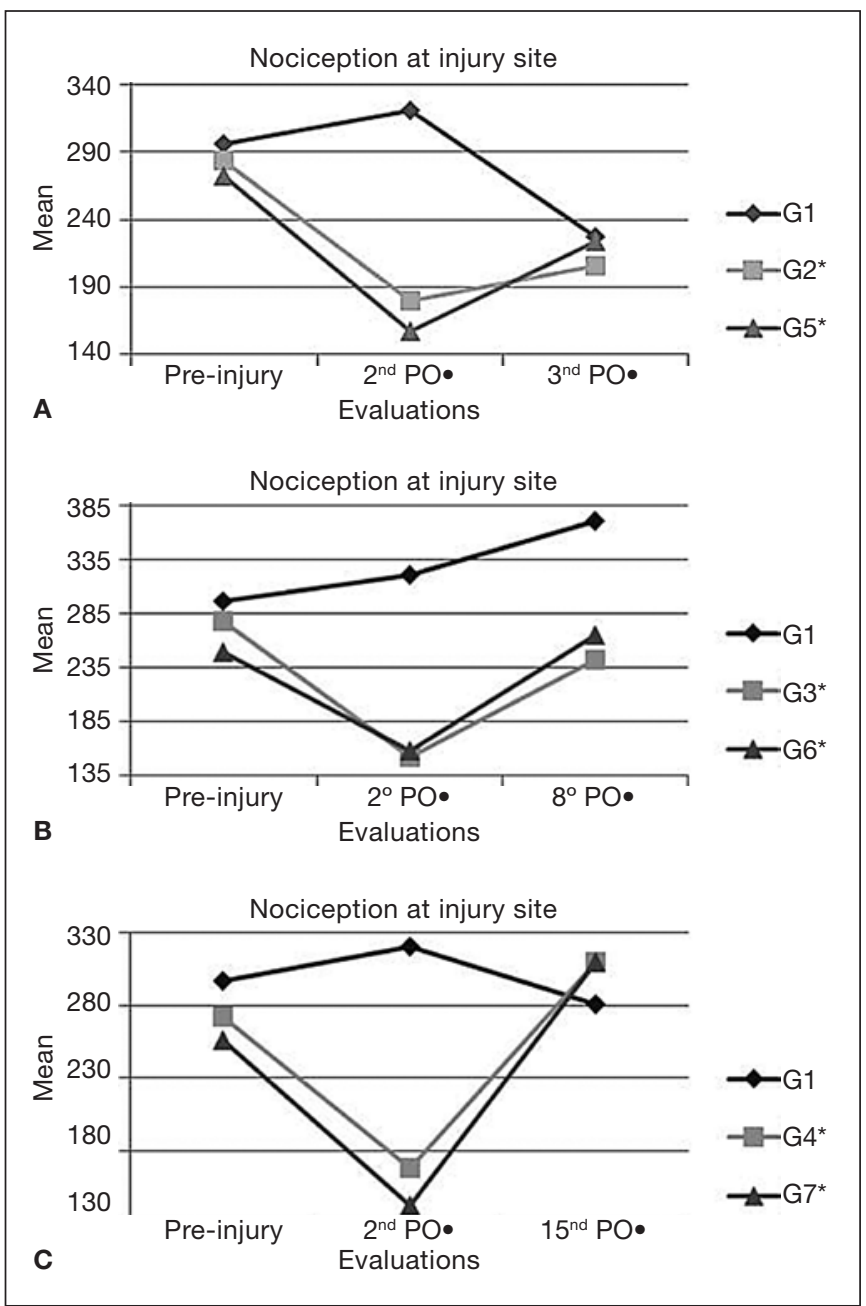

Figure 1. Evaluation of flinching threshold at injury site using digital Von Frey filament

* significant difference as compared to G1, • significant difference as compared to pre-injury evaluation, and $\bullet$ difference as compared to evaluation in $2^{\text {nd }} \mathrm{PO}$ day. higher values as compared to $2^{\text {nd }} \mathrm{PO}$ day, and this with lower values as compared to evaluation in the euthanasia day $\left(15^{\text {th }}\right.$ PO) (Figure 1C). Such results show no antinociceptive effects for treated groups.

\section{Nociception at plantar region}

According to nociception in the paw, G1, G2 and G5 had difference $[\mathrm{F}(2 ; 30)=22,6 ; \mathrm{p}<0,001]$. G2 and G5 thresholds were statistically lower than $\mathrm{G} 1$, the same being true for evaluation on the $2^{\text {nd }}$ and $3^{\text {rd }}$ PO day as compared to pre-injury (Figure $2 \mathrm{~A}$ ). In comparing G1, G3 and G6 values there has also been difference $[F(2 ; 30)=43,4 ; p<0,001]$, where G3 and G6 had lower thresholds as compared to G1, and evaluations of the $2^{\text {nd }}$ and $8^{\text {th }} \mathrm{PO}$ day had lower thresholds as compared to pre-injury (Figure 2B).

In analyzing G1, G4 G7 and pre-injury evaluations, $2^{\text {nd }} P O$ day and euthanasia day ( $\left.15^{\text {th }} \mathrm{PO}\right)$, it has been observed that G4 and G7 had lower thresholds as compared to G1, as well as evaluations of the $2^{\text {nd }}$ and $15^{\text {th }} \mathrm{PO}$ day which had lower thresholds as compared to pre-injury $[\mathrm{F}(2 ; 30)=23.6 ; \mathrm{p}<0.001]$ (Figure 2C). Again, no effects of cold therapy were observed.

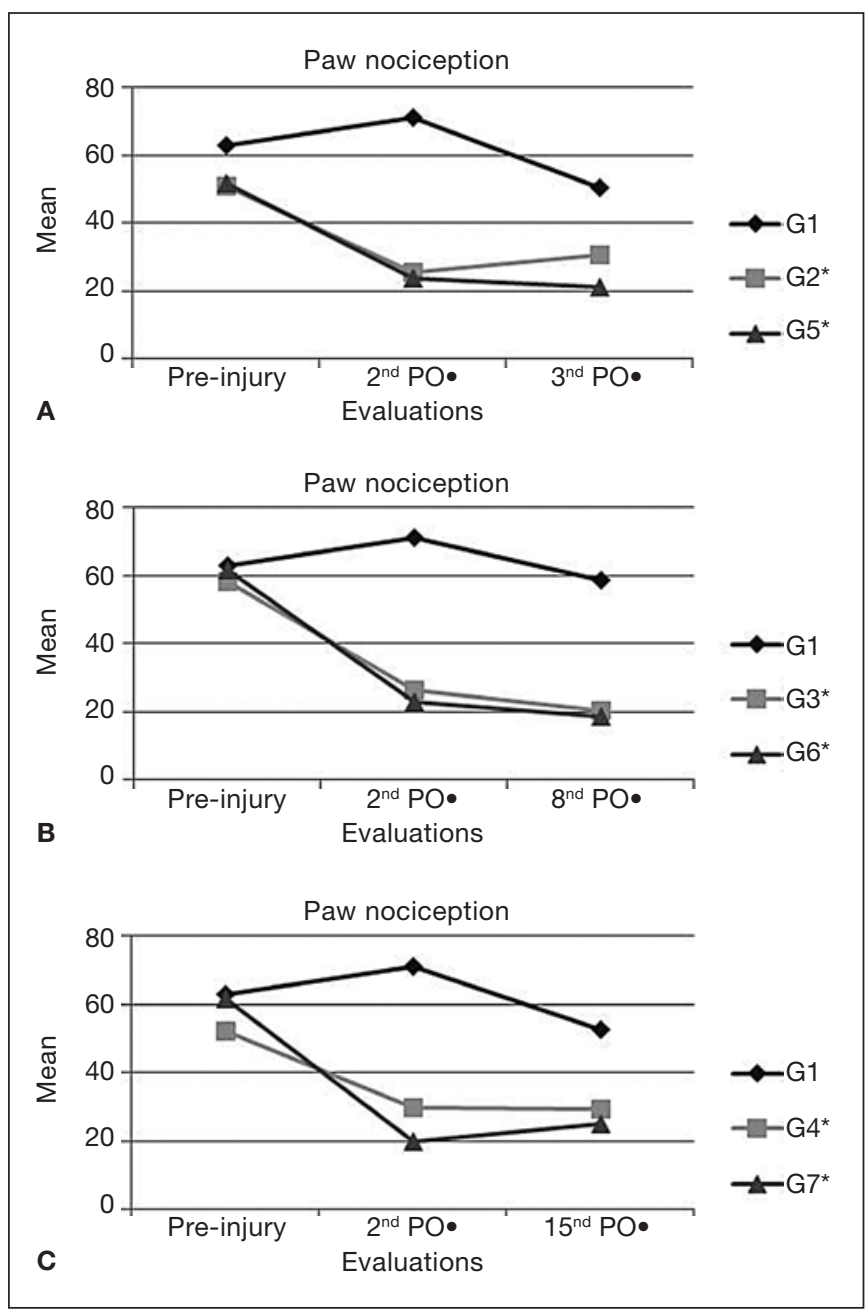

Figure 2. Flinching evaluation in plantar region using digital Von Frey filament

* significant difference as compared to $\mathrm{G} 1$, • difference as compared to pre-injury evaluation. 


\section{Edema}

According to edema evaluation performed in G1, G2 and G5, there has been significant difference $[F(2 ; 30)=4.3 ; p=0.023]$ in $3^{\text {rd }} \mathrm{PO}$ day evaluation which had higher values as compared to pre-injury (Figure 3A).

Results of G1, G3 and G6 have shown no significant difference between groups and between evaluations, with statistical significance $[\mathrm{F}(1.7 ; 30)=3.3 ; \mathrm{p}>0.05]$ (Figure $3 \mathrm{~B})$.

With regard to G1, G4 and G7 data, there has been statistical difference in $2^{\text {nd }} \mathrm{PO}$ day evaluation which had higher values as compared to pre-injury evaluation $\mathrm{F}(2 ; 30)=8.5 ; \mathrm{p}=0.01$ ] (Figure $3 \mathrm{C}$ ), with no effects of cold therapy in decreasing edema (Figure 3).

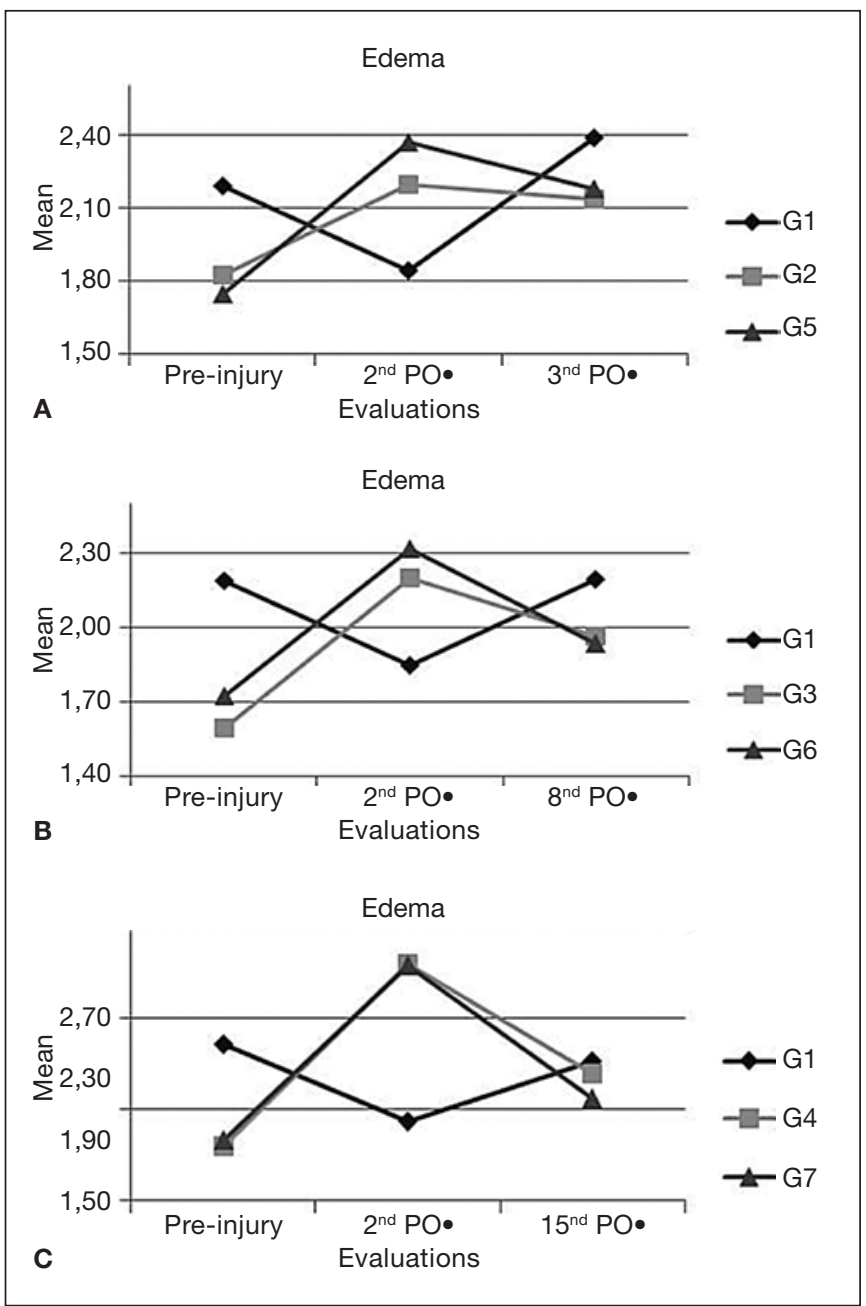

Figure 3. Evaluation of edema by hydropletismometry

- significant difference as compared to pre-injury evaluation.

\section{DISCUSSION}

This study has evaluated nociception and edema in rats submitted sciatic nerve compression model, treated with cold therapy, aiming at helping decreasing nociception and edema. Rats were chosen as experimentation animals because they have structure and response to injury similar to those found in human nerves ${ }^{11}$.

With regard to nociception, cold therapy could have helped analgesia due to decreased nervous conduction velocity inhibiting pain signals transmission to spinal cord posterior horn, in addition to acting as contra-irritating mechanism, by which pain transmission to the central nervous system is blocked $^{12-14}$; however, such results were not observed in this study.

With regard to edema evaluation, studies show that cold therapy may decrease it in cases of injury. In an experimental study with rats submitted to right knee synovitis and treated with immersion cold therapy for 20 minutes at $5^{\circ} \mathrm{C}$, edema was evaluated with metal caliper rule and nociception by flinching time, being that treatment was effective to decrease edema and nociception of animals? In a different study, edema was induced in the paw of female rats and was treated both by Bernard diadynamic currents (BDC) and cold therapy. Hydropletismography has shown that both treatments were significantly effective to decrease edema, with no difference between them ${ }^{15}$. However, injuries were not caused by peripheral nerve compression, as in our study.

In our study, nervous compression model has produced edema in groups evaluated in the $3^{\text {rd }} \mathrm{PO}$ day, showing that G2 and G5 had higher fluid volume change as compared to preinjury, and cold therapy was not effective to minimize edema. In addition, $15^{\text {th }} \mathrm{PO}$ day groups also had edema at $2^{\text {nd }} \mathrm{PO}$ day evaluation, being that G4 and G7 had similar behavior during evaluations. However, it is suggested that there has been decrease at final evaluation because values have decreased even not being significant which could have also helped increasing nociceptive threshold at injury site, since decreased edema may induce anagelsia ${ }^{6}$.

With regard to groups G3 and G6, they has similar behavior in all moments, without significant difference. It has to be stressed that initially, although without differences among groups, G1 had higher means as compared to other groups, but such variation was occasional, and may have occurred just by differences in animals' limbs volume, or by technical difficulties to perform the evaluation, since animals (except at injury time and before euthanasia) were not anesthetized, that is, they moved being just lightly contained by hand, including during cold therapy treatment.

However, although this study has not shown effect of cold therapy on peripheral nervous injury, no similar studies were found in the literature aiming and helping the discussion. So, we suggest new studies, addressing histological and molecular analyses, to check the efficacy of cold therapy on nervous injury, bringing basis for studies and treatments with humans.

\section{CONCLUSION}

Nervous compression has decreased nociceptive threshold and has generated momentary increase in paw volume, being that cold therapy has not produced effects both in nociception and edema. 


\section{ACKNOWLEDGMENTS}

Coordenaçáo de Aperfeiçoamento de Pessoal de Nível Superior (CAPES), for the master course scholarship and Fundação Araucária de Apoio ao Desenvolvimento Científico e Tecnológico, for financial resources to the project.

\section{REFERENCES}

1. Craig A. Entrapment neuropathies of the lower extremity. PM\&R. 2013;5(5 Suppl):31-40.

2. Wood MD, Kemp SW, Weber C, Borschel GH, Gordon T. Outcome measures of peripheral nerve regeneration. Ann Anat. 2011;193(4):321-33.

3. Faroni A, Mobasseri SA, Kingham PJ, Reid AJ. Peripheral nerve regeneration: experimental strategies and future perspectives. Adv Drug Deliv Rev. 2015;82-83:160-7.

4. Dubový P. Wallerian degeneration and peripheral nerve conditions for both axonal regeneration and neuropathic pain induction. Ann Anat. 2011;193(4):267-75.

5. Rocha AP, Kraychete DC, Lemonica L, de Carvalho LR, de Barros GA, Garcia JB, et al. [Pain: current aspects on peripheral and central sensitization]. Rev Bras Anestesiol. 2007;57(1):94-105. English, Portuguese.

6. Gutiérrez Espinoza HJ, Lavadi Bustamante IP, Méndez Pérez SJ. Revisión sistemática sobre el efecto analgésico de la crioterapia en el manejo del dolor de origen músculo esquelético. Rev Soc Esp Dolor. 2010;17(5):242-52.

7. Hanks J, Levine D, Bockstahler B. Physical agent modalities in physical therapy and rehabilitation of small animals. Vet Clin North Am Small Anim Pract. 2015;45(1):29-44

8. Bridge PM, Ball DJ, Mackinnon SE, Nakao Y, Brandt K, Hunter DA, et al. Nerve crush injuries - a model for axonotmese. Exp Neurol. 1994;127(2):284-90.

9. Moreira NB, Artifon EL, Meireles A, Silva LI, Rosa CT, Bertolini GR. A influência da crioterapia na dor e edema induzidos por sinovite experimental. Fisioter Pesqui. 2011;18(1):79-83.

10. Vivancos GG, Verri WA Jr, Cunha TM, Schivo IR, Parada CA, Cunha FQ, et al. An electronic pressure-meter nociception paw test for rats. Braz J Med Biol Res. 2004;37(3):391-9.

11. Savastano LE, Laurito SR, Fitt MR, Rasmussen JA, Gonzalez Polo V, Patterson SI Sciatic nerve injury: a simple and subtle model for investigating many aspects of nervous system damage and recovery. J Neurosci Methods. 2014;227:166-80.

12. Corti L. Nonpharmaceutical approaches to pain management. Top Companion Anim Med. 2014;29(1):24-8.

13. Barrot M. Tests and models of nociception and pain in rodents. Neuroscience. 2012;211(1):39-50.

14. Gosling AP. Mecanismos de açăo e efeitos da fisioterapia no tratamento da dor. Rev Dor. 2012;13(1):65-70.

15. Oda JY, Garnés FL, Martins AJ, Takemura OS. Efeitos da crioterapia vs correntes diadinâmicas na reduçáo do edema de pata em ratas. Arq Cienc Saúde UNIPAR. 2014;18(2):107-11. 